\title{
The Sound of a New Era: On the Transformation of Auditory and Urban Experience in the Long Fin de Siècle, I880-I930
}

Daniel Morat

HCM 7: 591-609

DOI: $10.18352 / \mathrm{hcm} .573$

\begin{abstract}
In his I930s memoir 'Berlin Childhood around I900', Walter Benjamin recollects the ringing of the telephone as a sound that sharply interrupted the quiet of his middle-class family home and signalled the beginning of a new era. Following Benjamin's lead, the article retraces the decades around I 900 as an era of transformation in which fundamental changes in the urban environment, in society and technology also lead to a crucial change of auditory experience. The new sounds of this era, from telephone rings to city noises to gramophone recordings, and the ways in which contemporaries dealt with them can therefore be used as a kind of sonic probe to detect broader transformations of modern experience.
\end{abstract}

Keywords: experience, media history, modernity, sound history, urban history

\section{Introduction $^{\mathrm{I}}$}

Sounds have a history. If you are a telecommunications nostalgist, you may have set your smart phone's ring tone to 'old phone', a sound that spirits us back to the past. It is the sound of a bygone era. Yet around 
I900, it was the sound of a new era. In his I930s memoir 'Berlin Childhood around I900', Walter Benjamin wrote of the telephone:

\begin{abstract}
Not many of those who use the apparatus know what devastation it once wreaked in family circles. The sound with which it rang between two and four in the afternoon, when a schoolfriend wished to speak to me, was an alarm signal that menaced not only my parents' midday nap but the historical era that underwrote and enveloped this siesta. ${ }^{2}$
\end{abstract}

In what follows, I will take the ringing of the telephone and these lines by Benjamin as a point of departure, first to pursue some general considerations on the methodology of sound history, then to enter somewhat more specifically into the 'sound of the new era' during the decades around I900. In order to do that, I will draw on my research on the auditory cultures of fin de siècle Berlin which I have conducted over the last couple of years. This will allow me to share some of the methodological problems that I have encoutered during this research and some of the findings I have made as an historian venturing into the realm of sound.

\title{
Sound History and Auditory Experience
}

Let me begin with the general deliberations. On a very fundamental level, the quotation from Benjamin's memoir leaves no doubt that although Benjamin heard the same ringing we can still hear today, as an audio document or from an old telephone set, he heard it with different ears from ours. What for us is a nostalgic sound was for him an 'alarm signal' proclaiming the end of a whole 'historical era'. This divergence in perception may initially seem a rather obvious point to make. If we engage the fundamental methodological and theoretical questions of sound history, however, the apparently banal insight acquires an axiomatic significance - because it shows that every history of sound must simultaneously be a history of hearing. One might feel a kind of Rankeian curiosity to know 'how it really sounded'. That curiosity is also at work in many present-day attempts to reconstruct past sounds, whether as computer simulations or as part of 'living history' reenactments. But, to cite Mark M. Smith's example, if you stand next to an original American Civil War cannon and fire it, you will hear it with 
your own present-day ears, and will not be able to imagine how the same noise sounded to the soldier on the battlefield, that is, what it meant to him. ${ }^{3}$

'Meaning' is a key concept here. 'Sounds carry meaning', Smith points out dryly in Listening to Nineteenth-Century America. ${ }^{4}$ In sound history or the history of hearing, what is at stake is always the reconstruction of meanings that belonged, or were ascribed, to the particular sounds in question. That, in turn, can be achieved only by means of historical contextualization. To quote Smith again: 'Sounds and their meanings are shaped by the cultural, economic, and political contexts in which they are produced and heard'. 5 On that basis, auditory history only makes sense as part of a more general history in which sound and context illuminate each other.

To support this crucial point, one could cite another pioneer in the history of the senses. Alain Corbin, author of Village Bells: Sound and Meaning in the Nineteenth-Century French Countryside, argues in an essay on the historical anthropology of the senses that this undertaking cannot be limited to simply drawing up an 'inventory of the sensations' around particular historical situation, in other words to ascertaining what could be heard and seen, smelled and tasted in that environment. Instead, one must 'discern the ways in which the senses were educated and employed' - the social practices that attached themselves to the senses. ${ }^{6}$

Interest in historical sounds, then, is always an interest in the social relationships and systems of meaning within which those sounds were embedded. The question 'How did it really sound?' immediately poses a new question: 'How was it really heard?' Reflecting this dual perspective, in recent years the term 'soundscape', coined by the Canadian composer and sound scholar R. Murray Schafer, has enjoyed great popularity. ${ }^{7}$ Emily Thompson offers a succinct and striking definition: 'Like a landscape, a soundscape is simultaneously a physical environment and a way of perceiving that environment; it is both a world and a culture constructed to make sense of that world' ${ }^{8}$ The culture named in the second half of that sentence is often referred to as auditory culture. The two concepts of soundscape and auditory culture initially guided my own research into the auditory experience of the metropolis around I90o.

However, I have certain doubts about the explanatory power of the soundscape concept. ${ }^{9}$ One objection concerns its implied focus on the 
reception of sound. The naming of the 'physical environment' of sounds and their subsequent interpretation by historical actors locates those actors' agency primarily in terms of reception or appropriation. Yet sounds are not only perceived and charged with meaning; first of all, they are generated. It is therefore necessary to add a third, active dimension to the soundscape's twofold aspect. If, like Corbin, we emphasize acoustic practices, this will embrace not merely the practices of interpreting and appropriating sound, but equally, and chronologically antecedent to these, the practices of sound generation. In a volume on music as a means of identity formation, Christian Jansen discusses the exertion of agency by means of music, the 'music act' in analogy to the speech act. ${ }^{10}$ I argue that we can expand that use of the term to consider acoustic practices in general as 'sound acts'. ${ }^{11}$

Rather than going into more detail on sound acts in this sense, I will address a second conceptual expansion, which is the relationship of sound and transformation in the course of modernization processes. That is because the concept of soundscape has a tendency to produce static descriptions of a particular situation. Although many studies using the concept are concerned with phenomena of change (not least Murray Schafer's own descriptions of the transformation from a hi-fi to a lo-fi soundscape) there is no dynamic of change inherent in the term itself. When I first examined the auditory culture of the decades around I900, my key assumption was that this was an epoch of accelerated social and cultural transformation and that we could expect to see a parallel transformation in auditory culture. To describe those changes, I chose to draw more heavily on the notion of the transformation of auditory experience. But what does that concept involve?

The 'long' fin de siècle, from approximately I880 to I930, has frequently been described as an epoch of transformation. It saw the climax of fundamental societal processes such as industrialization, urbanization and population growth and the rise of nation states, the bourgeoisie and capitalism - processes that shaped the whole of the nineteenth century in Europe and North America, though in Germany especially towards the end of the century. ${ }^{12}$ But other processes of transformation culminated in Germany in those decades as well, such as an increasingly technicized and mediatized world of work and leisure (the result of the Second Industrial Revolution and its scientific and technological innovations), the acceleration of communication and transportation 
fostered by such innovations, the 'fundamental politicization' of society even before the introduction of parliamentary democracy, ${ }^{13}$ the beginnings of consumer society, and the first stages of globalization in the context of European colonialism and an expanding global economic system. ${ }^{14}$

A crucial element of the long fin de siècle as a distinct transformational phase of modernity is that these shifts and their culmination in the decades around I900 are not only something recognized as such retrospectively, by historians. They were already experienced as transformative processes by contemporary observers, not infrequently as a form of crisis, with many people feeling overwhelmed by the changes they faced. The crisis aspect of this experience of transformation was articulated not least in the loss of leverage for traditional models of the social order, generating a need for new models. This relationship between basic processes and models of social order is the crux of Christof Dipper's definition of Moderne, a term covering both modernity and modernism. Moderne, according to Dipper, is an artistic and societal self-description that goes back to the last quarter of the nineteenth century, when it encapsulated the sense of having reached a cultural threshold. ${ }^{15}$

In defining Moderne through the "transformation of temporal experience', Dipper is referring to Reinhart Koselleck and his now classic description of the gap between 'space of experience' (Erfahrungsraum) and 'horizon of expectation' (Erwartungshorizont) that opened up in the transitionary period around I800. ${ }^{16}$ The concept of "experiential transformation' (Erfahrungswandel) also derives from Koselleck. ${ }^{17}$ 'Experience' in Koselleck's sense embraces not merely the bare experiencing of an event or process, but its mental appropriation and interpretation. Experiences, as Jörn Leonhard puts it, reflect 'the interpretive appropriation of experienced reality'. ${ }^{18}$ Elsewhere, Leonhard explains Koselleck's concept of transition period or Sattelzeit: 'Transition societies are marked by an accelerated and critical disruption of experiences and their associated patterns of interpretation and communication. The transformation of traditional patterns of experience entails a search for new ways of interpreting such disruptions, of making them communicable and thus of appropriating experiential transformation in a meaningful way'. ${ }^{19}$ This appropriation takes place partly on the discursive and linguistic level of fully articulated interpretive models, but also 
partly in the emergence of new patterns of social action or forms of habitus. ${ }^{20}$

This understanding of 'experience' is fundamentally historical. Interestingly, the notion of 'sonic experience' has recently been discussed in sound studies as a concept that could possibly allow to disconnect sonic effects from the representations and significations attached to them in auditory culture. ${ }^{21}$ This tends to make the concept ahistorical and puts it in danger of an 'uncritical romanticization of the sonic experience'.$^{22}$ In contrast to that, I am interested in applying a historical approach to the analysis of sound culture by stressing the transformational character of auditory experince itself.

\section{The Transformation of Auditory and Urban Experience Around 1900}

Having defined the decades around I900 as an epoch of experiential transformation triggered by the processes of modernization, I can now return to Benjamin's ringing telephone and address the specifically auditory and urban dimensions of this transformation. Let us recall the passage quoted above: the sound of the telephone ringing in the afternoon, Benjamin wrote, 'was an alarm signal that menaced not only my parents' midday nap but the historical era that underwrote and enveloped this siesta.' For Benjamin, then, the ringing of the telephone was an acoustic emblem of transformation. As an 'alarm signal', it announced the arrival of a new era that was irrupting into the quiet of the old one. In his Arcades Project, Benjamin portrayed that previous age as an age of dwelling:

The nineteenth century, like no other century, was addicted to dwelling. It conceived the residence as a receptacle for the person, and it encased him with all his appurtenances so deeply in the dwelling's interior that one might be reminded of the inside of a compass case, where the instrument with all its accessories lies embedded in deep, usually violet folds of velvet. ... The twentieth century, with its porosity and transparency, its tendency toward the well-lit and airy, has put an end to dwelling in the old sense. ${ }^{23}$

In the bourgeois interior of the late nineteenth century, the telephone initially appeared to Benjamin as a foreign body. Its ringing was a 
disturbing noise. It signalled not only the beginning of a new era, but also the exterior intruding into the interior; as such, it contributed to the increasing 'porosity' of the bourgeois apartment and threatened the culture of the bourgeois subject. In the I920s, Alfred Döblin had described both telephone and radio as making 'the outside into a here': 'Every apartment is blown up, no one lives alone under his roof and in his own four walls'. ${ }^{24}$

It is significant that this dismantling of the apartment by the telephone, this penetration of the outdoors into the indoors, occurred acoustically. Benjamin's 'folds of velvet' suggest a muffled sonic backdrop where loud noises were out of place. The 'compass case' of the bourgeois apartment, fitted with all its accoutrements, was also intended to protect its inhabitants from noise. The loudness of the telephone's ringing thus draws it into the context of controversy over big-city noise, a debate that was becoming more heated around I900, fuelled by increasing population density and the motorization and electrification of public transport. ${ }^{25}$ At stake in these discussions were the boundaries between public and private, the penetration of alien sounds into one's own four walls, endangering the home's function as a site of rest, contemplation or intellectual production. In his polemic Der Lärm (Noise), the cultural philosopher Theodor Lessing, who founded the German Noise Abatement Society in 1908, listed the telephone's ringing among the numerous noises that disrupted his intellectual work:

Hammers bang, machines rattle. Butchers' wagons and bakers' carts rumble past the house before sunrise. Countless bells ring incessantly. A thousand doors open and slam closed.... Now the telephone rings. Now the horn heralds an automobile. Now an electric car clatters by. A train passes over the iron bridge. Right across our aching heads, right across our best thoughts. ${ }^{26}$

For Lessing, these noises were a torment to the nerves. It is thus no coincidence that the debate on noise was intimately related to discussions on nervosity, which around 1900 was widely perceived as emblematic of the era. ${ }^{27}$

This is not the place for a more detailed exploration of either Lessing's anti-noise society or the debate on nervosity, but the question of nerves brings us to Georg Simmel. As I have mentioned, one characteristic of the transformation processes of the long fin de siècle was 
that contemporary actors were already reflecting upon them. That also applies to intellectuals' scrutiny of rapid urbanization. Contemporaries were struck by the impact of urban transformation on the patterns of experience and perception among big-city inhabitants: they observed that changing life conditions were reflected in changes to the mentality and habitus of people in the metropolises. Starting in the late nineteenth century, a growing body of literary, journalistic and proto-sociological writing began to address urbanization, delineating the emergence of a new kind of human being: the 'metropolitan type'.$^{28}$ Perhaps the most famous example of such writing is the I903 essay 'The Metropolis and Mental Life' by the philosopher and sociologist Georg Simmel. In the essay, Simmel sought the "psychological foundation, upon which the metropolitan individuality is erected', and found it in the 'intensification of the life of the nerves due to the swift and continuous shift of external and internal stimuli' ${ }^{29}$ In response to this intensification, wrote Simmel, the metropolitan type developed a 'blasé attitude' and 'reserve', the 'intellectualistic quality' of which acted as a protection of subjective life against the violations of the big city. ${ }^{30}$

This reference to the violations perpetrated by the metropolis amply reveals Simmel's culturally pessimistic reservations about city life, which he regarded with great ambivalence. ${ }^{31}$ His text was nonetheless seminal for later urban sociology and urban ethnography examining mental adaptations to the conditions of city life. In I985, Gottfried Korff coined the term 'inner urbanization' to articulate this interest in the city's intellectual peculiarities..$^{32}$ The concept is also fruitful for an exploration of urban auditory experiential transformation, because it describes a dynamics of change, a changing response to the new stimulus structures afforded by the metropolis (including, of course, the structures of its acoustic stimuli) and the gradual formation of new interpretive patterns and forms of habitus.

Simmel's reference to the 'intensification of the life of the nerves' is productive in a further respect, in that it leaves open the question of how the life of the nerves has been intensified, towards pathological nervosity or towards enhanced attentiveness and sensitivity. In this sense, even traffic noise was not necessarily regarded as impairing intellectual life. Quite the contrary: it might be seen as a stimulus to the intellect. Edmund Wengraf, for example, responded to Lessing's call for a 'right to silence' by postulating a 'right to noise'. 'Let us be frank: City 
dwellers like we are actually cannot live without this street noise. It is the mental stimulation of our days and the lullaby of our nights' ${ }^{33}$

But traffic noise was not the only source of the 'intensification of the life of the nerves'. Another was the diverse and burgeoning culture of music and entertainment in big cities. Unlike music in the concert hall, where the audience was becoming quieter and quieter in this period, music in the public space typically demanded a form of distracted listening. Starting from the mid-nineteenth century, listening to art music became a matter of listening silently and with concentration, yet listening to popular music usually occurred simultaneously with other activities such as eating and drinking, chatting and dancing, even working. ${ }^{34}$ This distracted form of musical listening was (and still is) frequently construed as defective by music criticism and musicology. If it is not measured against some normative standard of concentrated listening, however, it turns out to be a distinct auditory practice that required listeners to deal with different auditory stimuli at once, thereby training their ears - very much a form of 'inner urbanization'. To attend a garden concert was to deliberately expose oneself to acoustic simultaneity and to practise dealing with it.

We can gain an impression of that process from a sketch of a balmy summer evening in the concert garden of a musical café on Berlin's Kurfürstendamm boulevard, published in early September I9Io in the daily Der Tag. Even before the music began, wrote reporter Erich K. Schmidt, the garden was full of 'commotion, tinkling, laughing, humming':

In the corner, next to the Böcklin Gate, on the bandstand beneath a red-andwhite striped awning, sit the musicians. The first violin and leader of the band, without the usual forelock, taps the music stand with his bow. The music rises shrilly like a bird roused from sleep. Offenbach and Strauss ripple softly along, Wagner roars and whirrs in between. Light, coquettish waltzes sway up and down in waves, fade like sparks in the high blue sky... Every now and again, the noise of the street booms and hisses into the garden; ruthless, brutal; devours everything with its shameless clattering. Or the toots of car horns roll into the fray, in vain against the Tannhäuser overture. ... The band in the corner, under the red-and-white awning, gives its last gleeful shouts, ends with a crash - bang! ... The commotion, tinkling, laughing, humming now seems to regain intensity. ${ }^{35}$ 
Schmidt's somewhat sarcastic tone indicates his critical take on this form of musical practice, even if he does not articulate this explicitly. Other writers made no secret of their contempt for the 'general musical mania', with Theodor Lessing describing the 'general restaurant and coffee-house concert' as an 'abominable custom'.${ }^{36}$ Certainly, the ubiquity of popular music in the urban space played a prominent role in the controversy over city noise. ${ }^{37}$ But noise-abatement activists such as Lessing were not only protesting against the absolute volume of the big city's acoustic backdrop; they also deplored what was, in their ears, a barbaric mixing of different sounds. We might argue that such mixing was precisely what typified the polyphonic and polyrhythmic city. And the everyday encounter with popular music was what made it possible to adjust to this new urban structure of sound.

\section{Mediatization and the Transformation of Auditory Experience}

In Walter Benjamin's writings, with which I began this paper and to which I now return, we also find indications of an 'intensification of the life of the nerves' in Simmel's sense and the experiential change that it prompted. Human beings, wrote Benjamin in the earliest version of his famous essay 'The Work of Art in the Age of Mechanical Reproduction', were confronted with highly developed technology as a 'second nature' that, despite having invented it, they had 'long since ceased to master'. They were dependent on a kind of 'training' in order to cope with the 'new tasks of apperception' posed by the technological world. ${ }^{38}$ For Benjamin, the cinema was the key site where the eye could be trained in such adaptation: 'Film enables people to practise the new apperceptions and reactions that are required to deal with an apparatus whose role in their lives increases almost daily. To make the prodigious technical apparatus of our time an object of human innervation is the historic task in whose service film finds its true meaning' ${ }^{39}$ Benjamin assumed a high degree of analogy between film and modern metropolitan life:

The film is the art form that is in keeping with the increased threat to his life which modern man has to face. Man's need to expose himself to shock 
effects is his adjustment to the dangers threatening him. The film corresponds to profound changes in the apperceptive apparatus - changes that are experienced on an individual scale by the man in the street in big-city traffic, on a historical scale by every present-day citizen..$^{40}$

In 'On Some Motifs in Baudelaire', Benjamin similarly noted that moving through the 'traffic of a big city' involves the individual 'in a series of shocks and collisions', subjecting 'the human sensorium to a complex kind of training'. ${ }^{4 \mathrm{I}}$ This analysis of perception need not be reduced to vision alone. Peter Bailey, for example, has proposed transferring the visual codification of perception in modernity, and especially in the modern metropolis, to the codification of hearing: 'It may be instructive ... to extend to hearing Benjamin's proposition that distraction has superseded contemplation as the habitual state of modern visual reception. Thus we may understand modern street noise as a montage of sounds with shocklike juxtapositions of dissimilar and constant dissolves met and mastered by a newly developed sonic subconscious'. ${ }^{42}$

Benjamin's notions of innervation and the training of apperception, in other words, can also be applied to the acoustic stimulus structure of the big city and the cognitive adaptations necessitated by that structure. Unlike Simmel, however, Benjamin grounds these concepts in a theory of media. Benjamin applied his notion of innervation not directly to the 'shock effects' of big-city traffic itself, but to film, the medium that was to 'make the prodigious technical apparatus of our time an object of human innervation' and thus train apperception. This raises the question of what role should be attributed to the acoustic media with regard to acoustic innervation in the big city. How did mediatization and the transformation of auditory experience interact in the long fin de siècle?43 Can one speak of an auditory apperception training similar to the visual apperception training described by Benjamin? Sound collage, comparable with the montage techniques of film - techniques with a particularly high profile in Benjamin's argument - had been available since the beginning of the I930s. Walter Ruttmann's radio piece Weekend of I930 is the most celebrated example, although it found no real imitators for many years. ${ }^{44}$ Radio had only began to spread in the I920s, and did not become a mass medium in the true sense until World War II.

The gramophone, in contrast, was already in wide use by 1900. Offering the opportunity to record and play back sound for the very 
first time, it contributed substantially to changing listening habits. In the case of the gramophone, though, the training of apperception consisted less in becoming habituated to shock-like perceptual stimuli than in learning ways to deal with disembodied voices and noises. This brings me back to the telephone, because telephone users, too, first had to learn how to deal with disembodied voices. In the telephone chapter of his 'Berlin Childhood' piece, Benjamin recounts that the child's fright arose not solely from the 'alarm signal' of the ringing, but equally from the sounds that entered his ear through the telephone:

Whether because of the structure of the apparatus or because of the structure of memory, it is certain that the noises of the first telephone conversations echo differently in my ear from those of today. They were nocturnal noises. No muse announces them. The night from which they came was the one that precedes every true birth. And the voice that slumbered in those instruments was a newborn voice. ${ }^{45}$

The place from which the telephone voice came into the receiver here appears as a prenatal beyond. In the last section of the chapter, Benjamin switches that to a postmortem beyond, as the telephone voice becomes the voice of a ghost:

At that time, the telephone still hung - an outcast settled carelessly between the dirty-linen hamper and the gasometer - in a corner of the back hallway, where its ringing served to multiply the terrors of the Berlin household. When, having mastered my senses with great effort, I arrived to quell the uproar after prolonged fumbling through the gloomy corridor, I tore off the two receivers, which were heavy as dumbbells, thrust my head between them, and was inexorably delivered over to the voice that now sounded. There was nothing to allay the violence with which it pierced me. Powerless, I suffered, seeing that it obliterated my consciousness of time, my firm resolve, my sense of duty. And just as the medium obeys the voice that takes possession of him from beyond the grave, I submitted to the first proposal that came my way through the telephone. ${ }^{46}$

This is an impressive description of the perceptual effect that could result from the medium's separation of the voice from its bearer. According to John Durham Peters, the chief purpose of the telephone is 
to conjure up presence: "“Come here, I want you," said Bell to Watson in the first telephone call, and this utterance is the symbol and type of all communication at a distance - an expression of desire for the presence of the absent other' ${ }^{47}$ Benjamin's reference to the spiritualist medium points in the same direction, but adds an uncanny dimension to the conjuring of the absent person's presence. From the outset, part of the fascination of early audio media was their ability to make the absent vocally present. In the case of the phonograph and the gramophone, this was especially relevant for the voices of the dead. ${ }^{8}$ Thus, an early set of instructions for 'speaking machines' praised their role in individual and collective memory:

Treasured relatives, dear friends and famous contemporaries who have long been resting in the earth, speak to us again after many years, with the same vivacity and warmth, we now feel carried back by the wax cylinder to the happy days of our youth - we hear the speech of people who lived countless years before us, whom we never knew, and whose names only come down to us through history. ${ }^{49}$

In the days before answering machines and voicemail, the telephone could not bridge time as the phonograph did; it could only bridge space. Nevertheless, by comparing the voice from the telephone with the voice from beyond the grave, Benjamin embedded the phone in the same discursive context. ${ }^{5} \mathrm{He}$ did not, however, concede that 'vivacity and warmth' were mediated by the telephone. Rather, the voice from the telephone appeared to him as an alien power, a nocturnal noise unannounced by any muse. Similarly, Marcel Proust explained how the familiar voice of his grandmother felt completely alien to him during a telephone call. Stripped of her facial expressions and gestures, it became 'mere voice'. ${ }^{51}$

It is particularly interesting to note that Benjamin describes this media effect as being unmediated: 'There was nothing to allay the violence with which it pierced me.' The medium of the telephone did not exert a filtering or distancing effect, but produced immediate, direct proximity. And just as the speaker on the telephone became all voice, the listener became all ears, having lost command of his other senses. In this way, the telephone became a medium of command to which the child felt helplessly and submissively exposed. 
In the first sentence of the passage quoted above, Benjamin notes that it may be either the structure of the apparatus or the structure of memory that made the sounds of the first telephone conversations 'echo differently in my ear from those of today'. Probably, both apply: telephone sets around I900 differed in sound quality from those of I930, and memory does not simply preserve our sensory impressions, but changes them over time. Yet there may be a third reason, the effect of learning or habituation. The noises of the early telephone were alien because the whole apparatus was still strange; users had not yet learned to deal with its disembodied voices. That was true of the child receiving his first telephone call, but many adults, too, had to learn how to use the telephone in its early days. This is underlined by the many instructions for use that survive from the period. These both explain the technical utilization of the apparatus and offer rules of etiquette for telephone conversations, with tips on how to speak (slowly and clearly, but not necessarily loudly) and what to say (give your name at the start of the conversation, be brief). ${ }^{52}$

We may safely assume that in his later years, Benjamin no longer agreed unquestioningly to any proposal made over the telephone. By practising telephone conversation and becoming habituated to disembodied telephone voices, he no doubt attenuated their unmediated authority. Training in the use of new audio media, then, may also be regarded as a transformation of auditory experience. This notion, to conclude, seems better suited to describing the dynamics of change in the auditory culture of the long fin de siècle than the notion of soundscape. It also points beyond that epoch, revealing the perceptual distinction that I described at the start of this paper - the distinction between the ringing telephone as a sound of the old and the new era - to be the outcome of a historical process.

\section{Notes}

I The text of this article was translated by Kate Sturge; throughout, all quotations have been translated by her unless otherwise attributed.

2 Walter Benjamin, 'Berlin Childhood around I900', Walter Benjamin: Selected Writings. Volume 3, 1935-1938, Howard Eiland and Michael William Jennings (ed.) (Cambridge MA, 2003), 350. On the history of 
this text's origin and reception, see Anja Lemke, 'Berliner Kindheit um neunzehnhundert', Burkhardt Lindner (ed.), Benjamin-Handbuch: Leben, Werk, Wirkung (Stuttgart, 2006), 653-63.

3 Mark M. Smith, The Smell of Battle, the Taste of Siege: A Sensory History of the Civil War (Oxford, 2015), 3.

4 Mark M. Smith, Listening to Nineteenth-Century America (Chapel Hill NC, 200I), 266.

5 Ibid., 7.

6 Alain Corbin, Time, Desire and Horror: Towards a History of the Senses, trans. Jean Birrell (Cambridge, I995), I83, I86.

7 This is not the place to discuss Schafer's importance for sound studies, but see R. Murray Schafer, The Soundscape: Our Sonic Environment and the Tuning of the World (Rochester VT, I994).

8 Emily Thompson, The Soundscape of Modernity: Architectural Acoustics and the Culture of Listening in America I900-I933 (Cambridge MA, 2004), I.

9 On criticism of the concept, see also Ari Y. Kelman, 'Rethinking the Soundscape: A Critical Genealogy of a Key Term in Sound Studies', Senses \& Society 5:2 (2010), 2 I 2-34.

Io Christian Jansen, 'Einleitung: Musik als Mittel politischer Identitätsstiftung', Tillmann Bendikowski et al. (eds), Die Macht der Töne: Musik als Mittel politischer Identitätsfindung im 20. Jahrhundert (Münster, 2003), 9.

I I See Daniel Morat, 'Der Sound der Heimatfront: Klanghandeln im Berlin des Ersten Weltkriegs', Historische Anthropologie 22:3 (20I4). See also Karsten Lichau's contribution in this issue.

I2 On these fundamental processes, see Jürgen Kocka, Das lange I9. Jahrhundert: Arbeit, Nation und bürgerliche Gesellschaft (Stuttgart, 200 I).

I3 Hans-Peter Ullmann, Das Deutsche Kaiserreich I87I-I9I8 (Frankfurt am Main, I995), I 26.

I4 On the first globalization and 'global capitalism' before I9I4, see Jürgen Osterhammel and Niels P. Petersson, Globalization: A Short History, trans. Dona Geyer (Princeton, NJ, 2005); on processes of change around I900 more generally, Paul Nolte, 'I900: Das Ende des I9. Jahrhunderts und der Beginn des 20. Jahrhunderts in sozialgeschichtlicher Perspektive', Geschichte in Wissenschaft und Unterricht 47:5-6 (I996), 28 I-300.

I5 Christof Dipper, 'Moderne, Version: I.o', Docupedia-Zeitgeschichte, 25 August 20IO, http://docupedia.de/zg/Moderne, accessed 2 January 20I8. Dipper writes: "patterns of perception, experiences, discourses 
and language are not subordinate to structural transformation, but have a relationship of interaction with the basic processes.' See also Lutz Raphael, 'Ordnungsmuster der "Hochmoderne"? Die Theorie der Moderne und die Geschichte der europäischen Gesellschaften im 20. Jahrhundert', Ute Schneider and Lutz Raphael (eds), Dimensionen der Moderne: Festschrift für Christof Dipper (Frankfurt am Main, 2008), 73-9I.

I6 See Reinhart Koselleck, "Space of Experience" and "Horizon of Expectation": Two Historical Categories', Koselleck, Futures Past: On the Semantics of Historical Time, trans. Keith Tribe (New York, 2004), 255-76.

I7 Reinhart Koselleck, 'Erfahrungswandel und Methodenwechsel: Eine historisch-anthropologische Skizze', Koselleck, Zeitschichten: Studien zur Historik (Frankfurt am Main, 2003), 27-77.

I8 Jörn Leonhard, 'Erfahrung im 20. Jahrhundert: Methodische Perspektiven einer "Neuen Politikgeschichte", Norbert Frei (ed.), Was heißt und zu welchem Ende studiert man Geschichte des 20. Jahrhunderts? (Göttingen, 2006), I56-63, at I57.

I9 Jörn Leonhard, 'Erfahrungsgeschichten der Moderne: Von der komparativen Semantik zur Temporalisierung europäischer Sattelzeiten', Ute Schneider and Lutz Raphael (eds), Dimensionen der Moderne: Festschrift für Christof Dipper (Frankfurt am Main, 2008), 549-66, at 549.

20 See Jörn Leonhard, 'Politisches Sprechen im Zeitalter der Extreme: Überlegungen zu einer Erfahrungsgeschichte der Moderne', ZeitRäume: Potsdamer Almanach des Zentrums für Zeithistorische Forschung (2010), I07-26, at I I 2 .

2I See Brian Kane, 'Sound Studies Without Auditory Culture. A Critique of the Ontological Turn', Sound Studies. An Interdisciplinary Journal I:I (20I5), 2-2I.

22 Bruce Johnson, 'Sound Studies Today. Where Are We Going?', Joy Damousi and Paula Hamilton (eds), A Cultural History of Sound, Memory and the Senses (New York, London 2017), 7-22, at I5.

23 Walter Benjamin, The Arcades Project, trans. Howard Eiland and Kevin McLaughlin (Cambridge MA, I999), 220-2 I.

24 Quoted in Helga Lange-Garritsen, Poetisches Telefonbuch (Heidelberg, I987), 27.

25 See Karin Bijsterveld, Mechanical Sound: Technology, Culture, and Public Problems of Noise in the Twentieth Century (Cambridge MA, 2008); Peter Payer, 'The Age of Noise: Early Reactions in Vienna, I870-19I4', Journal of Urban History 33:5 (2007), 773-93. 
26 Theodor Lessing, Der Lärm: Eine Kampfschrift gegen die Geräusche unseres Lebens (Wiesbaden, I908), I4-5. On Lessing and his noise abatement society, see also Lawrence Baron, 'Noise and Degeneration: Theodor Lessing's Crusade for Quiet', Journal of Contemporary History I 7: I (I982), I65-78; Matthias Lentz, "Ruhe ist die erste Bürgerpflicht": Lärm, Großstadt und Nervosität im Spiegel von Theodor Lessings "Antilärmverein", Medizin, Gesellschaft und Geschichte I3 (I994), 8 I-I05.

27 For an overview, see Joachim Radkau, Das Zeitalter der Nervosität: Deutschland zwischen Bismarck und Hitler (Munich, I998); on the links between the debates on nervosity and noise, Daniel Morat, 'Urban Soundscapes and Acoustic Innervation around I900', Robert Beck, Ulrike Krampl and Emmanuelle Retaillaud-Bajac (eds), Les cinq sens de la ville: Du Moyen Age à nos jours (Tours, 20I3), 7 I-83.

28 Friedrich Lenger, 'Großstadtmenschen', Ute Frevert and Heinz-Gerhard Haupt (eds), Der Mensch des I9. Jahrhunderts (Frankfurt am Main, I999), 26I-9I.

29 Georg Simmel, 'The Metropolis and Mental Life' (I903), Simmel, On Individuality and Social Forms: Selected Writings, Donald N. Levine (ed.) (Chicago, I97I), 324-39, at 325; translation emended.

30 Ibid., 329, 33 I, 326.

3 I See Dietmar Jazbinsek, 'The Metropolis and the Mental Life of Georg Simmel: On the History of an Antipathy', Journal of Urban History 30: I (2003), I02-25.

32 Gottfried Korff, 'Mentalität und Kommunikation in der Großstadt: Berliner Notizen zur "inneren" Urbanisierung', Hermann Bausinger and Theodor Kohlmann (eds), Großstadt: Aspekte empirischer Kulturforschung (Berlin, I985), 343-6I.

33 Quoted in Payer, 'Age of Noise', 783.

34 For more detail on this and the following points, see Daniel Morat, 'Music in the Air - Listening in the Streets: Popular Music and Urban Listening Habits in Berlin around I900', Christian Thorau and Hansjakob Ziemer (eds), The Oxford Handbook of Music Listening in the I9th and 2oth Centuries (Oxford, 2019), 335-53.

35 Erich K. Schmidt, 'Musikcafé am Kurfürstendamm', Der Tag (3 September I9I0).

36 Lessing, Der Lärm, 69.

37 See Daniel Morat, 'Sounding Out Urban Space: Berlin Street Music around I900', Colloquia Germanica 46:4 (2013), 33 I-42. 
38 Walter Benjamin, 'Das Kunstwerk im Zeitalter seiner technischen Reproduzierbarkeit (Erste Fassung)', Benjamin, Gesammelte Schriften, ed. Rolf Tiedemann and Hermann Schweppenhäuser (Frankfurt am Main, I 99I ), I/2, 43 I-69, at 444, 466. The third version of the essay is translated as 'The Work of Art in the Age of Mechanical Reproduction' (I939), trans. Harry Zohn, Benjamin, Illuminations: Essays and Reflections, ed. Hannah Arendt (New York, I968), 2 I7-52.

39 Benjamin, 'Das Kunstwerk', 444-45.

40 Benjamin, 'Work of Art', 250.

4I Walter Benjamin, 'On Some Motifs in Baudelaire' (I939), trans. Harry Zohn, Benjamin, Illuminations: Essays and Reflections, Hannah Arendt (ed.) (New York, I968), I75.

42 Peter Bailey, Popular Culture and Performance in the Victorian City (Cambridge, I998), 206.

43 For the term 'mediatization', which conceptualizes the 'interrelation between changes in media and communications on the one hand, and changes in culture and society on the other', see Nick Couldry and Andreas Hepp, 'Conceptualising Mediatization: Contexts, Traditions, Arguments'. Communication Theory 23:3 (2013), I9I-202, at I96.

44 See Wolfgang Hagen, 'Walter Ruttmanns Großstadt-Weekend: Zur Herkunft der Hörcollage aus der ungegenständlichen Malerei', Nicola Gess, Florian Schreiner and Manuela Schulz (eds), Hörstürze: Akustik und Gewalt im 20. Jahrhundert (Würzburg, 2005), I83-200.

45 Benjamin, 'Berlin Childhood', 349.

46 Ibid., 350.

47 John Durham Peters, Speaking into the Air: A History of the Idea of Communication (Chicago IL, I999), I80.

48 See Jonathan Sterne, The Audible Past. Cultural Origins of Sound Reproduction (Durham NC, London, 2003), 287-92.

49 Alfred Parzer-Mühlbacher, Die modernen Sprechmaschinen (Phonograph, Graphophon und Grammophon), deren Behandlung und Anwendung: Praktische Ratschläge für Interessenten (Vienna, I902), I07.

50 On this discursive context, see also Jochen Hörisch, Der Sinn und die Sinne: Eine Geschichte der Medien (Frankfurt am Main, 200I), 250-5I. In the radio discourse of the period when Benjamin was writing 'Berlin Childhood', the spiritualist quality of the voices from the ether still resonated. See Habbo Knoch, 'Die Aura des Empfangs: Modernität und Medialität im Rundfunkdiskurs der Weimarer Republik’, Habbo Knoch and 
Daniel Morat (eds), Kommunikation als Beobachtung: Medienwandel und Gesellschaftsbilder I880-I960 (Munich, 2003), I33-58. See also Friedrich Kittler, Gramophone, Film, Typewriter, trans. Geoffrey Winthrop-Young and Michael Wutz (Stanford CA, 2006), I 2: 'Media always already provide the appearances of specters'.

5I Stefan Münker, 'Vermittelte Stimmen, elektrische Welten: Anmerkungen zur Frühgeschichte des Virtuellen', Stefan Münker and Alexander Roesler (eds), Telefonbuch: Beiträge zu einer Kulturgeschichte des Telefons (Frankfurt am Main, 2000), I85-98, at I86.

52 See Clemens Schwender, Wie benutze ich den Fernsprecher? Die Anleitung zum Telefonieren im Berliner Telefonbuch I88I-I996/97 (Frankfurt am Main, I997).

\section{About the Author}

Daniel Morat is Adj. Professor at the History Department of the Free University Berlin and works as an exhibition curator. He received his $\mathrm{PhD}$ at the University of Göttingen in 2006. His major fields of research are modern European and transatlantic history, intellectual history, sensory history, history of media and communications, and urban history. From 2012 to 2016 he directed the international research network 'Auditory Knowledge in Transition: An Epistemic History of Listening in Modernity'. He is the editor of Sounds of Modern History: Auditory Cultures in I9th- and 20th-Century Europe (Berghahn Books, 20 I4) and, together with Hansjakob Ziemer, the co-editor of Handbuch Sound: Geschichte - Begriffe - Ansätze (Metzler Verlag, 20 I8).

E-mail address: daniel.morat@fu-berlin.de 